\title{
Subject Identifier Type Code
}

National Cancer Institute

\section{Source}

National Cancer Institute. Subject Identifier Type Code. NCI Thesaurus. Code $C 94161$.

A coded value specifying the kind of subject identifier. 